\title{
A Closer Look at Collaborative Lesson Planning: Shaping Pre-Service Teachers Professional Identity in the Teaching Practice Program
}

\author{
Khoiriyah Khoiriyah $^{1 *}$, Utami Widiati ${ }^{2}$, and Bambang Yudi Cahyono ${ }^{3}$ \\ ${ }^{123}$ Universitas NegeriMalang \\ "Corresponding author. Email: khoiriyah.iain@gmail.com
}

\begin{abstract}
Extensive studies on teacher identity have been reported; however, little attention has been given to how pre-service teachers shape their professional identity in online teaching practice program. The present study examines EFL preservice teachers' professional identity situated in collaborative lesson planning that encompasses three stages: preplanning, whilst-planning, and post planning. Dialogic reflection was deployed to find out the view and commitment of six pre-service teachers about teaching. The findings of the study revealed that collaborative lesson planning can shape pre-service teachers' professional identity. It also increases their motivation and self-efficacy before they get into the actual teaching in the classroom.
\end{abstract}

Keywords: Pre-service teachers' identity, collaborative lesson planning, online teaching practice

\section{INTRODUCTION}

Teacher education plays a pivotal role in building teacher professional identity because it is an ideal starting point to instil pre-service teachers' awareness and the strong feeling of becoming a teacher. To meet the need for professional teachers' qualifications, preservice teachers are required to equip themselves with adequate teachers' knowledge, skill [1] and competence. Teaching practice in the school site that encompasses planning, enacting, and reflecting provides an opportunity for pre-service teachers to shape their professional identity [2].

To begin with, preparing the lesson is a stage where pre-service teachers or teachers can learn how to design their instruction and enact it confidently [3]. However, to avoid the "missing link" between the theory and the practice in the placement [4]. there is a need for a linking connection between teacher educators and school-based mentors as bridging the gap between the theory and the practice through collaborative teamwork. For this reason, collaborative lesson planning is expected to be able to strengthen pre-service teachers in building their professional identity. The present study is an attempt to address an issue of how to build preservice teachers' professional identity situated in a collaborative lesson planning that encompasses preplanning, whilst-planning, and post-planning.

\section{THEORETICAL FRAMEWORK}

\subsection{Shaping Identity Formation Situated in} Collaborative Lesson Planning

Identity can be viewed as how a person understands her/himself and her/his relationship with others in the past and their future [5] and how they make interrelationship with others in social life [6]. In the field of Institution identity, instructional design can be viewed as a self-conception that grows naturally, institutionally, and socially. Regarding this concept, improving pre-service teachers' pedagogical competence specifically in designing a lesson plan as teacher professional identity should be developed by selfdevelopment and self-improvement, act professionally, behave respectfully, and interact with others verbally or non-verbally with a colleague, infrastructure, and students. Thus, professional identity situated in the teaching practice encompasses not only pedagogical and professional competence but also personal and social competence.

\section{METHOD}

This study was situated in an online teaching practice program in two private senior high schools in a rural area in Bondowoso, East Java. Six pre-service teacher participants were involved in the online teaching practice program, one male and five female. Dialogic reflection using Google meet and Zoom meetings situated in collaborative lesson planning were recorded 
and translated into English. The complete data was analyzed within these four stages: 1) labeling, 2) sorting data, 3) categorization, and 4) analyzing data [7].

\section{FINDINGS AND DISCUSSION}

\subsection{Shaping Identity Formation Situated in}

Collaborative Lesson Planning

Before teaching practice, shared-spaced coaching was performed for the sake of building pre-service teachers' identity. For the purpose, dialogic reflection was deployed to get closer relationship with pre-service teacher participants. This shared-spaced coaching situated in a collaborative lesson planning was mediated by teacher mentor participants and teacher educator participants. Pre-planning was performed to identify pre-service teachers' views, beliefs, perceptions about teaching and teacher as a future profession. In the stage of whilst-planning, pre-service teachers are required to equip themselves with knowledge, skill, and competence. In the stage of post-planning, reflection knowledge reveals pre-service teachers' reflective skills.

\subsubsection{Pre-Planning}

Teaching practice in a school site is challenging for pre-service teachers because they are not only working with peers as they perform in a teaching practicum but also with a teacher mentor, school principal, real students, stakeholders, and curriculum artifacts. Educational policies which are stated in the national standard of education have bearing on innovation in the design of language instruction. Pre-service teachers as teacher candidates are prepared to be professional teachers to shape their professional development in their future careers. They are required to be able to improve their knowledge and skill to design their own planning before they enact it in the physical classroom for the first time. However, being a teacher is not their choice as their future profession as stated by PsT 1, PsT 3, and PsT 5.

In the stage of pre-planning, three pre-service teacher (PsT) participants did not show their intention in teaching due to the unwillingness to be a teacher as their future profession. PsT 1, PsT 3, and PsT 5 have different reasons why they did not have an intention to be a teacher as their future career. Pre-service teachers who did not have an identity did not know themselves and realize that they are professional teacher candidates. PsT 5 used a metaphor to express her disappointment " $I$ felt I am lost in the jungle". It indicates that she did not have the motivation to be a professional one [8] who has a responsibility to do the best in the school site. PsT 1 shows his reluctance to be a teacher because of a stereotype and perception toward the teaching profession. He perceived that being a teacher is not a professional job for his future career. His views and perception about teaching and his future career lead him to shape his identity formation [9]. Meanwhile, PsT 3 expressed her unwillingness to be a teacher due to the unsuccessfulness in pursuing her obsession. As a result, she felt stress, unmotivated learner, and frustrated learner. This inconvenience situation brings her to reconstruct her role as a teacher candidate [10].

\subsubsection{Whilst-Planning}

To achieve professionalism and identity construction, pre-service teachers are required to equip with knowledge as a starting point to understand the educational policy. For this reason, online classroom teaching practice should be provided by subject-matter knowledge (SmK), content knowledge (CK), pedagogical knowledge (PK), technological knowledge (TK), and curriculum knowledge (CK). To start with, Subject-matter knowledge which is considered as the core of pre-service teachers' knowledge is the basis of the teaching profession. PsT 3 did not have any selfconfidence because of a lack of speaking ability.

How can I teach speaking skills in an online class, my speaking skill is still low even teaching the speaking skill of a descriptive text?(Dialogic reflection 2)

Speaking skill is one of professional competence that should be possessed by teachers and pre-service teachers. It is considered as the core competence and a practical knowledge key to teaching as a professional career. Second, content knowledge is interdisciplinary knowledge in which English as subject-matter knowledge is taught across the curriculum based on the level of the school (e.g. social science, mathematics, biology). Subject-matter knowledge and content knowledge are two different sides that belong to teachers' professional competence. Shulman (1987) states that comprehending the subject-matter and the content knowledge is an essential component to acquire before teaching practice because it is not only a basis of knowledge but also the core knowledge [11].

Third, pedagogical knowledge is viewed as an understanding of the cognitive, psychological, and social theories of teaching and learning. It is considered as a knowledge of pedagogy that should be acquired by pre-service teachers to deliver subject-matter and content in the classroom (e.g. teaching strategies, material development, instructional media, classroom management, and assessment). PsT 2 and PsT 4 could not show their pedagogical knowledge well due to the lack of understanding about compatible assessment of particular skill and often a mismatch in deciding teaching strategy as well as learning objectives.

How can I assess the topic "Showing
care". is it belong to to speaking or
reading? I could not decide on the
appropriate assessment. (Dialogic
reflection 2)

PST 4 I could not figure out how to teach a song. (Dialogic reflection 2)

PsT 2 shows her confusion and doubtful how to assess her students' competence in teaching speaking. Meanwhile, PsT 4 felt the reluctance to design her lesson plan in teaching a song due to the lack of 
pedagogical knowledge and skill as a whole. This is in line with Hayati, Widiati \& Furaidah (2018) findings that assessment is a confusing part of classroom practices which is participants could not differentiate between how to assess the students' knowledge and how to assess the students' skills [1]. However, dialogic reflection during collaborative lesson planning among pre-service teachers, a teacher mentor, and a teacher educator leads pre-service teachers to have new insight and perception.

Forth, technological knowledge is an understanding of how technology is exploited as an instructional medium to deliver materials in the classroom either in synchronous and asynchronous modes (e.g. video, PPT, Whats App, YouTube, web, e-mail, and LMS). In the beginning, PsT 1 stated that being a teacher is not his goal because he should provide complicated preparation. However, bringing technology in the online classroom encourages him to be more creative in designing technology-based materials and designing scoring rubrics to assess students' knowledge, skill, and attitude [12] as well as more confident in designing an instructional plan [13].

PsT 1 Aha.....I have an idea to create a technologybased materials such as a video which will be uploaded on Youyube in my lesson plan. The students shoud comment on a column beneath. (Dialogic reflection 3)

Sixth, curriculum knowledge is viewed as a knowledge of educational practices organization that encompasses aims/objectives, learning activities, learning resources, and evaluation/assessment. Curriculum knowledge should be acquired by preservice teachers in order to know how they interact with curriculum artefacts (e.g. curriculum guidelines, syllabus, and lesson plan) [14]. Pre-service teachers are required to design their instructional plan as a part of professional development in which lesson planning is considered as a way to build their professional identity before teaching practice [15].

\subsubsection{Post-Planning}

Reflection knowledge is viewed as a bridge where the theory and practice meet. Reflection is not only conducted after teaching practice but also conducted before teaching to build pre-service teachers' professional identity during planning the action. Wellprepared lesson planning [16] will affect the readiness of pre-service teaching practice in an online classroom setting before entering the physical classroom. Postplanning is provided to equip pre-service teachers to be reflective practitioners [17].

\section{CONCLUSION}

The finding of the study revealed that collaborative lesson planning can significantly shape pre-service teachers' professional identity. Collaborative lesson planning also increases pre-service teachers' motivation and self-efficacy before entering the physical classroom as well as transforms their identity formation. This research also informs that collaborative lesson planning situated in online teaching practice allows pre-service teachers to strengthen their willingness of being a teacher for their future profession.

\section{AUTHORS' CONTRIBUTIONS}

The contribution of the present study is to provide a practical evidence regarding how pre-service teachers, teacher mentor, and supervisor collaborate in a lesson planning contribute to having a professional identity.

\section{ACKNOWLEDGMENTS}

The authors would like to express their deepest gratitude to PNBP LPPM (Lembaga Penelitian dan Pengabdian Masyarakat) Universitas Negeri Malang 2021 who have sponsored this research. We also thank the editors and the reviewers for their kindest considerations.

\section{REFERENCES}

[1] N. Hayati, U. Widiati, \& Furaidah. Understanding Reasons Behind Student Teachers' Pedagogical Decisions. Electronic Journal of Foreign Language Teaching. 15 (2) (2018), pp. 256-270

[2] G. Zhu, P. M. Iglesia, \& K. Wang. Examining Chinese and Spanish preservice teachers' practicum teaching experiences: a transformative learning perspective. Journal of Education for Teaching. (2015) DOI: 10.1080/02607476.2019.1708623

[3] L. L. Amalia, U. Widiati, Y. Basthomi \& B. Y. Cahyono. Reflective practice on lesson planning among EFL teacher educators. Indonesian Journal of Applied Linguistic. 10(1) (2020), pp. 153-160

[4] T. Russell. Using the practicum in pre-service teacher education programs: Strengths and weaknesses of alternative assumptions about the experiences of learning to teach. In F. Hoban (Ed.), The missing links in teacher education design: Developing a multi-linked conceptual framework (2005) (pp. 135-152). Springer. https://doi.org/10.1007/ 1-4020-3346-X_8

[5] B. Norton. Identity and language learning: Gender, ethnicity and educational change. (2000). Harlow, UK: Pearson Education.

[6] J. Danielewicz. Teaching selves: Identity, pedagogy, and teacher education. (2001). Albany, NY: State Uni-versity of New York (SUNY) Press.

[7] A., B. N. Saban, Kocbeker, \& A. Saban.."Prospective Teachers' Conceptions of Teaching and Learning Revealed Through Metaphor Analysis.'Learning and Instruction17 (2) (2007) 123-139

[8] M. A. Flores. Feeling like a student but thinking like a teacher: a study of the development of professional identity in initial teacher education. Journal of Education for Teaching. (2020). https://doi.org/10.1080/02607476.2020.1724659

[9] H. P. Widodo, F. Fang \& T. Elyas The construction of language teacher professional 
identity in the Global Englishes territory: we are legitimate language teachers'. Asian Englishes. (2020). DOI: 10.1080/13488678.2020.1732683

[10] J. D. Bain, R. Ballantyne, C. Mills, \& N. C. Lester - Reflecting on practice: Student teachers' perspectives. (2002). Flaxton: Post Pressed.

[11] S. Shulman. Knowledge and teaching: Foundations of the new reform. Harvard Education Review,57(1) (1987),1-22. doi:10.17763/ haer.57.1. j463w79r56455411.

[12] J. B. Harris \& M. J. Hofer. Technological Pedagogical Content Knowledge (TPACK) in Action: A Descriptive Study of Secondary Teachers' Curriculum-Based, Technology-Related Instructional Planning. Journal of Research on Technology in Education.43 (3) (2011). pp. 21 1229

[13] H.O. Kapici, \& H. Akcay. Improving student teachers' TPACK self-efficacy through lesson planning practice in the virtual platform. Educational Studies. (2020) DOI: 10.1080/03055698.2020.1835610

[14] J. Choppin, A. R. McDuffie, C. Drake, \& J. Davis. Curriculum ergonomics: Conceptualizing the interactions between curriculum design and use. International Journal of Educational Research. (2018). 92.75-85

[15] G. Zhu , M. Rice, G. Li, \& J. Zhu. EFL Student Teachers' Professional Identity Construction: A Study of Student-Generated Metaphors Before and After Student Teaching. Journal of Language, Identity, and Education. (2020).DOI:10.1080/15348458.2020.1777872

[16] U. Widiati \& N. Hayati. How well-prepared are Indonesian pre-service teachers to develop their future students' intercultural competence. In S. Zein (Ed.), Teacher education for English as a lingua franca: Perspectives from Indonesia. Routledge. 2019.

[17] B. Larrivee. Transforming Teaching Practice: Becoming the critically reflective teacher. Reflective Practice. 1(3), (2000), 293-307, DOI: 10.1080/713693162 